\title{
Economic Governance in Gabon: Assessment of the Plan Stratégique Gabon Emergent on the Business Environment
}

\author{
Herbert Mba Aki \\ Department of Political Science and Diplomacy, Hanyang University, Seoul, South Korea \\ Email: nzeherbert87@yahoo.fr
}

How to cite this paper: Mba Aki, $\mathrm{H}$. (2019). Economic Governance in Gabon: Assessment of the Plan Stratégique Gabon Emergent on the Business Environment. Open Journal of Political Science, 9, 17-37. https://doi.org/10.4236/ojps.2019.91002

Received: October 3, 2018

Accepted: November 10, 2018

Published: November 13, 2018

Copyright $\odot 2019$ by author and Scientific Research Publishing Inc. This work is licensed under the Creative Commons Attribution International License (CC BY 4.0).

http://creativecommons.org/licenses/by/4.0/

\begin{abstract}
The present study aims to identify the existing reforms introduced by the recent economic diversification policy of the government of Gabon called Plan Stratégique Gabon Emergent. It assesses the current stage of reforms aiming to enable the business environment. Empirical part of our research was carried out with evidence relating to the impact of regulatory reform on the business environment in Gabon. We used the World Bank Doing Business and Ibrahim Index of African Governance databases to provide indicators of the quality of regulatory governance from 2009 to 2018. Our key findings showed that the investment climate is still below the expectations. The current macroeconomic situation of the country due to the barrel price has limited the capacity of the government to finance its major reforms. Furthermore, the small size of the market weakens the potentiality of the country to attract foreign direct investments in non-extractive sectors. In brief, Gabon's diversification model shows some weaknesses due to non-existent coherent industrial policy empowering small medium-size enterprises through an effective financial framework favorable for entrepreneurship.
\end{abstract}

\section{Keywords}

Business Environment, Economic Diversification, Economic Governance

\section{Introduction}

In 2010, the government of Gabon established a new economic policy called Plan Stratégique Gabon Emergent ${ }^{1}$ (PSGE), in order to diversify its economy

${ }^{1}$ The Plan Stratégique Gabon Emergent (The Strategic Plan for an Emerging Gabon) has been established since 2010. The project is planned in 3 phases. In July 2012, the government published a document which highlights the objectives for the period 2011-2016. The second phase started since 2017 and covers the period 2017-2019. The final phase would cover the period 2019-2025. 
and reduce its dependency on petroleum. The aims of the new economic policy are to improve diversification on revenue generation, sustainable development, good governance, human capital development, and infrastructural development. However, eight years after the implementation of the PSGE, the country's incomes remain highly dependent on natural resource and raw materials particularly petroleum and mineral resources. According to the World Bank, for the past five years, $80 \%$ of the country's exports depend on petroleum. Furthermore, the country ranks 167 out of 190 in the 2018 Doing Business report due to its business environment and the weak capacity to attract investors. Over the last decade, the country best ranking on the ease of doing business was 144 out of 189 in 2015 and 2008. This situation should recall the government of Gabon to further policies toward the business environment which are beneficial for the economic diversification. The pathway of the economic diversification goes necessarily through an effective economic governance that will enable investments favorable for sustainable growth and the development of the country.

Gabon's macroeconomic indicators show features of the so-called Dutch disease effect, and scholars agree that countries with substantial natural resources exports can become dependent of one volatile source of income which can destabilize the macroeconomy (e.g., Venables, 2016; Teksoz \& Kalcheva, 2016). Hence, the falling of oil prices since 2014 has affected Gabon's economy, its gross domestic product (GDP) has continuously slowed down from $4.3 \%$ in 2014 to $2.7 \%$ in 2016 (World Bank, 2017) and in 2017, the African Development Bank (AfDB) projected to be even lower (1.3\%). In addition, the public debt reached $60 \%$ of the country's GDP in 2017 according to the International Monetary Fund (IMF) compared to 31\% in 2013.

This study aims first to identify the existing reforms introduced by the PSGE to improve the economic governance; second, assess the current stage of reforms aiming to enable the business environment; third, analyze the effect of those reforms at the macro level and their impact on the Doing Business from 2009 to 2018; and fourth, develop the mean of our findings through policy recommendations necessary to improve Gabon economic governance.

Gabon has an important available commodity stock, so with an effective business environment, the country can attire more investments; but at the current stage of its economic development, reforms aiming to create local industries and encourage entrepreneurship continue to face major challenges. One of the major constraints facing local small and medium enterprises (SMEs) development is the access to finance. Hence, the private sector in Gabon is dominated by multinational enterprises operating in the mining and hydrocarbon sectors, but the contribution of foreign direct investment (FDI) to GDP remains very limited. This research contributes to both empirical and theoretical literature of the economic governance. It aims also to guide policymakers and decisionmakers. On the one hand, policymakers and governments must ensure to establish and choose economic reforms that have fast and profound socioeconomic im- 
pacts (Djankov et al., 2002; Klapper et al., 2006; Ndzana Olomo, 2011; Devarajan \& Fengler, 2013), and also reforms promoting industrialization. Thus, the country can create a value added on natural resources through the local transformation of commodities and contribute to the development of the private sector. On the other hand, this research is a contribution for the existing empirical and theoretical literature of institutions in resource-rich economies (see North \& Thomas, 1973; North, 1990; Knack \& Keeper, 1995; Sokoloff \& Engerman, 2000; Acemoglu et al., 2001, 2002, 2003; Mehlum et al., 2006; Robinson et al., 2006; Gelb \& Grasmann, 2010; Jones-Luong \& Weinthal, 2010; Sanders \& Sandvik, 2015) and their governance framework (e.g., Kaufmann \& Kraay, 2002; Grindle, 2004; Kaufmann et al., 2007b; Kurtz \& Shrank, 2007; Thomas, 2007; Arndt, 2008; Davis et al., 2012; Holmberg \& Rothstein, 2012).

Gabon is an interesting case because as despite a per capita gross national income (GNI) of US\$ 7170 in 2016 (The World Bank), higher than those of most sub-Saharan African (SSA) countries, one third of the population live below the poverty line. For a resource rich country considered as Middle-Income Country with less than two million inhabitants, its poverty level is comparable to that of low-income countries and this paradox represent an interest beneficial for the literature of development studies. Many scholars have highlighted the necessity of a political will as a starting point for enabling the business environment in African countries (Kirkpatrick et al., 2006; Nnadozie et al., 2008; Kirkpatrick, 2014). Nevertheless, the outcomes of the PSGE are unsatisfactory and their impact on the business environment insufficient at two different levels. First, the administrative burden in Gabon has consistently slowed the execution of reforms planned by the PSGE. Second, lack of financial resources to support key reforms due to the weak capacity of the government in planning, negotiation and project management, has handicapped the PSGE. In other words, poor governance and management of resources has consistently affected the efficiency of the PSGE; so, it is important to further alternative financial means in the framework of public-private partnerships (PPP). From this research, some key questions arise: what are the reforms implemented by the PSGE aiming to improve the business environment? How do they impact on the economic governance? What can be done to improve the efficiency of the reforms?

The rest of the paper is structured as follows: Section 2 contextualizes the study in the relevant existing literature. Section 3 sets out the methodology and data used to assess the PSGE. Section 4 presents the key findings and discussion. Section 5 concludes the paper and brings up the policy implications.

\section{Literature Review}

The PSGE aims to follow the pathway growth-diversification-development by reforming key economic sectors. This strategy also aims to enable the industrialization of the country; by undertaking the downstream processing of natural resources to create self-sustaining industries then contribute to a rapid socioe- 
conomic transformation. The dominant discourse on the economic diversification and growth points out economic institutions as key factor for the improvement of the economic governance. Many scholarships recognize the role played by the institutions in the economic development, but there are also an important range of empirical research where institutions play a minor role. In this section, we will discuss the relevant literatures for a better understanding of our case study. Hence, we organized the existing literature in two groups: the liberal institutional pluralism and the new structural economics. The former is represented by North (1990), Acemoglu et al. (2005), Rodrik (2008), and Brett (2009); and the latter by Chang (2002), Lin et al. (2011), Stiglitz and Lin (2013). The liberal institutional pluralism argues that institutions are necessary to attire investments. It emphasizes on the democratic rules and economic liberalism, thus institutional conditions for economic growth and political transformation; while the new structural economics focus on an approach that takes into account features in the analysis of economic development and the role of the government as the driver of the improvement of economic infrastructure for growth and integration of local and regional markets (Fofack, 2014).

The claim of the liberal institutional pluralism is that institutions that are the best for economic development are those that maximize market freedom and most strongly protect private property rights. The increasing demand for institutional reforms in developing countries has been encouraged and stimulated by research provided from within international organizations such as The World Bank (see Kaufmann et al., 1999, 2002, 2003, 2005, 2006, 2007a, 2008, 2009) and supplied by academic economists (Chang, 2010). Acemoglu et al. (2001) and La Porta et al. (2008) for example argue that economic growth is the result of a good investment and this latter is promoted by institutions that protect private property rights strongly and provide maximum economic freedom. Acemoglu et al. (2005) findings brought more practical insights arguing that "Economic institutions encouraging growth emerge when political institutions allocate power to groups with interest in broad-based property rights enforcement, when they create effective constraints on power-holders, and when there are relatively few rents to be captured by the power-holders'. However, the most challenging with the liberal institutional pluralism theory is well summarized by Rodrick (2012). He notes that different institutions could have similar outcomes while in different contexts the same institutions may give rise to different outcomes.

The liberal institutional pluralism theory has been questioned by the new structural economics scholars such as Chang (2002; 2010; 2011), Lin et al. (2011), Stiglitz and Lin (2013); claiming the synthesis of structuralism and liberal ideology without assuming a unified theory of economic development. According to Chang (2011), the direction of economic development could take a different pathway and wealth due to growth could create higher demands for political institutions with greater transparency and accountability, and also makes better institutions more affordable. Evidences from the $18^{\text {th }}$ century show that the rising of industrial capitalists supported the development of banking while 
the growing power of the working class led to the welfare and the protection of labor laws against the capitalists in the late $19^{\text {th }}$ and $20^{\text {th }}$ centuries in the USA (Lundvall \& Lema, 2014). This approach recognizes failure of both-state and market-in the economic development because the market remains the basic mechanism for effectively allocating resources and the state intervention is needed to constantly upgrade economic infrastructure.

The quality of infrastructure plays also a key role and has a significant effect on the business environment (Oumba, 2015). Nevertheless, African countries are at the early stage of the economic development and in this regard, they need to adapt their development policy by considering the global market without neglecting the local context. Therefore, good governance and political will would improve the organization and planning of the economic development (Ndzana Olomo, 2011; Ngangoue, 2016). Reforms capable of structurally transforming the economics, ease the international insertion, enable sustainable growth and ownership, easily adaptable to the local and international context, and based on short and long-term goals are essential for the development process. Ngangoue (2016) for example suggests the export diversification and regional integration to maintain sustainable growth and economic diversification within the Economic and Monetary Community of Central African States (CEMAC) ${ }^{2}$. Thus, CEMAC countries would gain by improving regional institutions and further regional integration. Due to the high potential of those countries in natural resources, they should put together their potentialities in five key sectors (Energy, agro-industry, forestry, farming and fishing, and mining and metallurgy) to develop the regional market. The positive outcomes would enhance the development of regional industrial capacity of the targeted sectors, development of regional infrastructures such as the road network, create employments, boost the economic growth, and benefit to the entire African region, especially narrow markets like Gabon to enlarge its market.

Poor governance and public management have also explained the failure of SSA countries in recent years to attract more FDI and build a strong entrepreneurship policy favorable for SMEs. Brixiova and Ncubi (2013) argue that sustainable growth need both public and private investments because the reliance of growth on the public investment can have a negative effect on private investment if neglected. This is why growth in Ethiopia has slowdown from 2013 while SSA countries' growth has been driven by commodity prices and the investment in both public and private, with a robust private consumption. The reality in most SSA countries is that governments have more consideration for prestigious investments in the form of large units rather than establishing strategies and actions for the creation of SMEs. Furthermore, reforms toward SMEs are much more responses to the constraints of the donors than a voluntary and well thought initiative. In Gabon like in many resource rich developing countries, scholars (e.g., Ndzana Olomo, 2011; Gambotti, 2014; Oumba, 2015; Ngangoue,

${ }^{2}$ Members of the Economic and Monetary of Central African States (CEMAC) are: Cameroon, Central African Republic, Chad, republic of Congo, Equatorial Guinea, and Gabon. 
2016) point out the fact that the non-respect and dysfunctional nature of the legal framework in Africa is deplorable and constitutes the main obstacle of the harmonious development of business. Therefore, there are many African countries making reforms without any concrete change on the socioeconomic. However, the quality of the business environment depends only partly on the quality of the legal framework, so rules are insufficient to guarantee the economic development.

Yet, evidences from the liberal institutional pluralism and the new structural economics request to consider the specific institutional and structural features at every stages of the development process. Each country needs to adapt its policy tools to local conditions. In Gabon these two approaches could be complementary regarding the major constraints of the economic development such as poor governance and the deficit of infrastructure. Moreover, strengthening institutions of good governance in the African context, where poverty widespread is associated with capital flight, could raise the prospects for domestic resource mobilization in support for infrastructure development. Evidences from the World Bank Doing Business ranking and other Indexes have shown that few African countries succeeded to adapt their development policies with local conditions. As a result, most resources rich SSA countries remain dependent of commodities and did not improve their infrastructure with the outcomes of their resources. In addition, poor governance and the political situation in SSA countries did not contribute to build a transparent framework in order to improve the public management of resources. Hence, without a political will and a certain level of transparency, it is uncertain that the economic development could improve institutions in SSA countries.

In brief, like Gambotti (2014), Kirkpatrick (2014), and Gisselquist \& Niño-Zarazúa (2015), we argue that the administrative burden and poor governance constitute the main weakness of SSA countries such as Gabon to enable a business environment in light of best international practices. The modernization of the administration and the improvement of the Government performance ${ }^{3}$ could play a key role in building the base of sustainability. It would for example lead to regulatory reforms to enable the market efficiency through a supportive and stable environment for investment, private sector development, and establish conditions for economic growth and development. Major reforms of the PSGE have been delayed and could not be implemented until 2014. Yet, there is no major improvement of the business environment nor governance; instead the GDP is continuously following the fluctuation of the prices of hydrocarbon and mineral resources due to the poor economic diversification.

\section{Methodology and Data}

Empirical part of our research was carried out with evidence relating to the im-

${ }^{3} \mathrm{~A}$ standard definition of government performance is the "capacity of governing authorities to provide public goods and services" (Bratton, 2013: p. 2). 
pact of regulatory reform on the business environment in Gabon. We used the World Bank Doing Business and Ibrahim Index of African Governance (IIAG) databases to provide indicators of the quality of regulatory governance from the period from 2009 to 2018. The World Bank Doing Business provides a cross-country dataset considering ten variables: starting a business, construction permits, employing workers, registering property, getting credit, protecting investors, paying taxes, trading across borders, enforcing contracts, and closing a business. The IIAG on its counterpart provides four indicators of governance: safety and rule of law, participation and human rights, sustainable economic opportunity and human development. Both constitute excellent boards to analyze the impact of economic and governance reforms on the business environment. Two other documents are essential for this research: the initial document of the PSGE (Plan Stratégique Gabon Emergent: Vision 2025 et Orientations Stratégiques 2011-2016) published in July 2012 by the government and the report of the current stage of the reforms (Plan Stratégique Gabon Emergent: Panorama des Réalisations 2009-2016) published in August 2016 by the Coordination Office of the PSGE. The document "Plan Stratégique Gabon Emergent: Vision 2025 et Orientations Stratégiques 2011-2016" highlights the main orientation of the economic diversification strategy of Gabon. It identifies four axes that constitute the foundation of the development strategy of the government. The first axis aims to establish a new development model that integrates human development, social equity, sustainable growth and environmental conservation. The second axis aims to adapt the education system to the need of the labor market. The third axis focuses on the infrastructures and it aims to improve the transport infrastructures through adequate road network and ports to facilitate the transportation of goods. Finally, the fourth axis aims the improvement of the economic governance through institutional and judicial frameworks beneficial to enable a good business environment. These four axes constitute the foundation that will serve to build the three pillars (primary sector, industries, and services) necessary for the economic takeoff of Gabon and lead the country to prosperity and finally reach the status of an emerging country. The second document, "Plan Stratégique Gabon Emergent: Panorama des Réalisations 2009-2016", is an overview of the evolution of the PSGE reforms from 2009 to 2016 and for the purpose of this research it contributes to have a better view of the current stage of the PSGE.

We organized the data throughout table and graphics and used process tracing methods and analytical narratives that examines the impact of governance on the economic performance. Our approach aims to explore the correlation between the economic governance of Gabon throughout the PSGE and the economic performance of the country. Though, the poor economic performance of Gabon in the recent years found an explanation in its dependency on commodities and the unattractive business climate of the country, therefore enabling an adequate business environment may contribute to improving economic perfor- 
mances. Hence, we found relevant to use data of the World bank Doing Business to identify reforms that are considered to have positive or negative impacts on the business environment by the ranking assessment. We took account of the ten variables of the ranking and obtained an asset to evaluate Gabon's economic governance trend over time. Whereas, the IIAG contributes to obtain a quantifiable tool to measure governance and monitor performance of Gabon on the one hand; and assess the progress over time to support the development of effective and responsive policy solutions on the other hand. The IIAG is standardized into a score between 0 and 100, the latter is the highest possible. The four components of the IIAG are used to determine the so-called Overall Governance, but for the purpose of our research we focus on two of its indicators: safety and rule of law and sustainable economic opportunity with emphasis on the latter. Though, the Overall Governance is useful to analyze the quality of regulatory governance, so it implies all the indicators of the index. The IIAG is also relevant for cross-country comparisons, but because of the difference of the social, political and economic contexts of each country, this approach has an insignificant impact on our findings. We use a comparative approach between the business environment assessment from the Doing Business ranking and the Overall Governance of the IIAG within the period 2009-2016 to build the mean of our findings. Our findings are based on the analyze of the current stage of the regulatory reforms and the macro-indicators of Gabon from diverse sources such as the World Bank, IMF, and the African Development Bank (AfDB). In our findings, we also take account of the earlier studies results on similar topics.

\section{Key Findings and Discussion}

\subsection{Investment Climate}

Reforms of the PSGE are considered as a political will from the government to bring socioeconomic changes and improve the country's macroeconomic indicators. Yet, it has also shown being difficult to launch reforms that will impact positively the business environment. Falling international oil prices reduced the ability of the government to pursue its investment program. The low barrel price since 2016 had negative impact on the petroleum taxes incomes, but also on other economic activities. The public investment plan, which plays a key role in the economic diversification, is highly dependent on oil incomes. Therefore, this situation affected the government policy toward the economic diversification and also the country economic growth. In addition, low budget revenues reduce the importance of the public investment with negative outcomes for the rest of the economy. The public investment estimated at around 22\% of the budget in 2016 has slightly decreased in comparison to 2015 (AfDB, 2016). The government also continued to accumulate debts from the private sector, under the particular form of credits or unpaid refund of value-added tax (VAT). Hence, regarding the Doing Business ranking of the World Bank from 2009 to 2018 and the IIAG, there is no considerable improvement from Gabon. Despite the gov- 
ernment-established initiatives demonstrating a commitment in making prosperity inclusive, challenges remain at every stage of the economic development. In terms of economic governance, the World Bank Doing Business 2018 highlighted business-related challenges in Gabon, ranking the country at 167 out of 190 countries assessed. There is a need to further internal and external investments that would improve the country's attractiveness.

Since 2014, the government has multiplied initiatives for the improvement of the investment climate and to foster enterprise development through the Gabon Investment Promotion and Competitiveness Project with the support of the World Bank. This project has three components. The first being institutional development to improve business climate. The second is to support enterprise development aiming to facilitate the operationalization of local companies and foster SMEs development. And the third component is the project management and public-private dialogue. Therefore, in 2014, the High Investment Council (HCI) was created but only functional since March 2017. The HCI aims to increase the amount of cooperation between the public and private sectors and stimulating private sector growth more generally and create jobs; it is a dialogue platform which would faster reforms toward the need of the diversification. The body did not appear to have convened, but it is expected to do so in the near future.

In September 2014, the government also launched the Gabon National Agency for the Promotion of Investment (ANPI-Gabon); a new agency created to both facilitate and promote investment in the country. The ANPI-Gabon acts as one-stop administrative shop for investors, as well as overseeing the implementation of the country's investment promotion plan, among other roles. It aims to reduce the amount of time to start a new company to less than 48 hours. This organization is functional since January 2018 and provides all services needed for the creation, modification, and closing of an enterprise in one place. But at this stage it is early to determinate its impact on the business environment. As of June 2018, the ANPI-Gabon registered 297 creation of new enterprises, 91 modifications, and 3 closing of enterprises (The official Journal of the Republic of Gabon, 2018). These numbers are from six months of activities that lead to think that the outcome is positive, even though more time is needed in order to assess the efficiency of this organization. Furthermore, the 48 hours objective for enterprise creation has not been reached yet, but the current initiatives are encouraging.

With regard to the above initiatives, efforts to attract foreign investors are made from the government counterpart, but major FDI remains oriented in mining and hydrocarbon; although in recent years, sectors such as timber industry and agribusiness-especially, rubber plants and oil palm-have contributed to the increase of FDI since 2012 (UNCTAD, 2018). The small domestic market, inadequate skilled labor and relatively high labor costs seem unfavorable for Gabon to attract investment in other activities. As a consequence, it almost 
forces the authorities to make an economic diversification around the three major activities (oil, mining, and forestry) that constitute the country's main incomes. The central strategy of the authorities is the creation of industrial clusters around commodity production on the basis of public-private partnership (PPP). Accordingly, the government with the partnership of Olam Ltd.-a Singapore-based corporation with interests in timber, palm oil, and rubber-has built in 2011 a Special Economic Zone (SEZ) for wood-processing with the aim to create a value-added in wood products. Two similar projects of SEZs are planning with the same corporation, one focused on chemical engineering based on the hydrocarbon products and another on the processing of agriculture products. In addition, since 2014 the country has started the local processing of manganese through the Moanda Metallurgical Complex. It consists of three plants, namely the Silico-Manganese Metallurgical Plant which has an annual production capacity of 65,000 tons; the Hydro-Metallurgical Plant which will produce 20,000 tons of manganese metal annually; and the Pyrometallurgical. This achievement has a symbolic and strategic importance to Gabon as it contributes to the country's industrialization and boosts its economy (African Development Bank Group (AfDB), 2011). However, the sub-sector is facing difficulties due to falling prices and continuous global over-production, but medium and long-term prospects remain favorable, given the development potential of emerging markets. The pathway of development decided by the authorities is a natural resource specialization model that have succeeded in developing strong and diversified economies in Nordic countries, yet there are still constraints surrounding the local business environment especially for startups.

\subsection{Business Environment Constraints}

Over the last decade, reforms made by the government to improve the business environment are apparently positive (see Appendix). In comparison to SSA countries that have a more attractive market, this progress is insufficient. Gabon has initiated only twelve reforms with positive outcomes on the ease of doing business environment from 2009 to 2018 while at the same period Rwanda has implemented 40 positive reforms and ranked 41 out of 190 economies in the 2018 Doing Business while Gabon ranked 167 on the ease of doing business.

Although Gabon has slightly improved the starting a business and getting a credit, dealing with construction permits has drastically fall from rank 60 to 149 between 2009 and 2018 (Table 1) among the 8 indicators of the Doing business ranking. Within the same period, the time for starting a business has been reduced from 58 days to 33 days, the cost of starting a business has also been reduced from $20.3 \%$ of the income per capita to $7.2 \%$, and the minimum capital has also been significantly reduced from $30.2 \%$ of the income per capita in 2009 to $2.5 \%$ in 2018 (Table 2). Yet, this improvement is small, and the country ranked 132 out 190 on starting business. For the other indicators Gabon's ranking is between 122 and 178. The expected result of the PSGE on the economics 
by 2025 -along with acceleration and economic diversification, poverty reduction, reducing societal inequalities, infrastructure development, and the sustainable management of resources for future generations-seems challenging to reach regarding the current economic development trend.

Compare to other SSA countries with a better ranking on the starting a business (Table 3), the time for creation of an enterprise needs to be reduced alongside with the other indicators of the Doing Business Ranking. Thirty-three days remain long for starting a business, so the one-stop-shop of the ANPI-Gabon carry a lot of expectations from entrepreneurs and investors. Nevertheless, the starting a business indicator solely is insufficient to enable the entire business environment. Countries with the best ranking in starting a business are not necessarily on the top of the ease of doing business. For example, among the top-five SSA countries on the starting a business (Niger, Mauritius, Burundi, Mauritania, and Côte d'Ivoire) only Mauritius is well ranked on the ease of doing business $\left(25^{\text {th }}\right)$ and the others ranked between 139 and 164 ranks.

Table 1. Gabon Doing Business ranking 2009 \& 2018.

\begin{tabular}{ccc}
\hline & 2018 Rank/190 & 2009 Rank/181 \\
\hline Ease of doing business & 167 & 151 \\
Starting a business & 132 & 148 \\
Dealing with construction permits & 149 & 60 \\
Registering property & 173 & 158 \\
Getting credit & 122 & 131 \\
Protecting investors & 160 & 150 \\
Paying taxes & 165 & 101 \\
Trading across borders & 169 & 128 \\
Enforcing contracts & 178 & 147 \\
\hline
\end{tabular}

Source: The World Bank, Doing Business 2018.

Table 2. Indicators of starting a business in Gabon 2009-2018.

\begin{tabular}{|c|c|c|c|c|c|c|c|c|c|c|}
\hline & 2018 & 2017 & 2016 & 2015 & 2014 & 2013 & 2012 & 2011 & 2010 & 2009 \\
\hline $\begin{array}{c}\text { Rank/ } \\
\text { Economies }\end{array}$ & $132 / 190$ & $152 / 190$ & $144 / 189$ & $135 / 189$ & $153 / 189$ & $157 / 185$ & $156 / 183$ & $153 / 183$ & $152 / 183$ & $148 / 181$ \\
\hline $\begin{array}{l}\text { Procedures } \\
\text { (number) }\end{array}$ & 8 & 7 & 7 & 7 & 7 & 9 & 9 & 9 & 9 & 9 \\
\hline $\begin{array}{l}\text { Time } \\
\text { (days) }\end{array}$ & 33 & 50 & 50 & 50 & 50 & 58 & 58 & 58 & 58 & 58 \\
\hline $\begin{array}{c}\text { Cost } \\
\text { (\% of income per capita) }\end{array}$ & 7.2 & 14.3 & 15.1 & 12.9 & 12.5 & 14.5 & 17.3 & 21.9 & 17.8 & 20.3 \\
\hline $\begin{array}{c}\text { Minimum capital } \\
\text { (\% of income per capita) }\end{array}$ & 2.5 & 10.8 & 11.4 & 19.6 & 19.3 & 22.3 & 26.4 & 32.7 & 26.5 & 30.2 \\
\hline
\end{tabular}

Source: The World Bank, Doing Business 2009-2018. 
Table 3. Indicators of starting a business: Gabon and top 5 SSA countries.

\begin{tabular}{cccccccc}
\hline & Gabon & Average SSA & Niger & Mauritius & Burundi & Mauritania & Côte d'Ivoire \\
\hline Rank (out of 190) & 132 & 125 & 24 & 40 & 42 & 43 & 44 \\
Procedures (number) & 8 & 7.6 & 3 & 5.5 & 3 & 4 & 4 \\
Time (days) & 33 & 24.0 & 7 & 5.5 & 4 & 6 & 7 \\
Cost (\% of income per capita) & 7.2 & 49.9 & 8.3 & 1.0 & 33.9 & 19.3 & 28.6 \\
Minimum capital (\% of income per capita) & 2.5 & 25.6 & 11.8 & 0.0 & 0.0 & 0.0 & 9.7 \\
\hline
\end{tabular}

Source: The World Bank, Doing Business 2018.

Therefore, the government of Gabon should, in addition of easing the starting of business, further reforms of the banking system alongside with the infrastructures. On the one hand, indigenous investors and SMEs lack of financing posed obstacles for their growth and their activities remain limited because few have the support of the banking sector. For example, it is difficult for SMEs to participate in the more lucrative deals in extractive resources. Reforms aiming entrepreneurship would call for the creation of supportive funds for startup and SMEs and/or the development of microfinance institutions (MFIs). The latter has contributed to empower population in number of African countries and the development of micro activities, but its role remains small in Gabon. On the other hand, the major part of the public investment should serve to develop the infrastructures especially electricity, the road network, and maritime transport in order to maximize the productivity of the existing industries and to connect the production hubs with the markets. The Enterprise Surveys (2009) provide us more information about the pathway policymakers should use as a board for public investments. Electricity (23.4\%) and transportation (14.6\%) are identified as the main obstacles for firms established in Gabon followed by corruption (10.3\%). These three main obstacles have different importance according of the size of the Firm. For small firms, electricity (22\%), access to finance (13\%), and transportation (12\%) constitute the main obstacles; for medium firms, electricity (28\%), transportation (17\%), and corruption (16\%); and for large firms, transportation (28\%), electricity (21\%), and the practice of informal sectors (12\%).

Regional and sub-regional market integration can have positive outcomes on the pathway economic diversification of Gabon. It would enlarge its narrow market, and also improve the quality of the infrastructures such as road network and maritime transport. Through the development strategies of the African Union (AU) and the new partnership for Africa's development (NEPAD) in the Regional Integration Strategy Paper prepared by the AfDB, Gabon is expected to play an important role in strengthening regional integration among the Economic Community of Central African States (ECCAS); and benefits from a market of over 120 million people within this economic space. However, the process of the market integration is complex and requests the intensification of dialogue and actions with the governments of Central African countries. 


\subsection{Governance Performance and Competitiveness}

The root of governance performance is based on transparency and regulation that will impact on the economic performance. Parry (2007) notes that transparency permits a clearer assessment of the past fiscal performance, current fiscal position, fiscal risks, and the future direction of fiscal policy. Recently, SSA countries are trying to catch up with the rules of the game to meet the requirements of the donors and attract investors because transparency in the end is about empowerment and trust between and among stakeholders. Transparency plays a key role in aid effectiveness, corruption, environmental degradation, enhance the well-functioning of financial markets, capital allocation, and in the efficiency of investment decisions (Durnev et al., 2009; Drabek \& Payne, 2001). Gabon authorities try to comply with the need of transparency and efforts are being made at both institutional and legal frameworks to improve the management of public property, particularly through the establishment of the National Commission for the Fight against Illegal Enrichment (CNLCEI) in 2003 and the National Agency for Financial Investigation (ANIF); and decrees issued in August 2015 that strengthen some penal provisions related to financial crimes. Though Table 4 shows that progress in economic governance needs to be sustained. The IIAG 2017 ranked Gabon 23 out of 54 countries with a score of 52.2 (slightly above average). The country has not improved much the governance during the last decade and remains at the same place as before the implementation of the PSGE for two main raisons: lack of transparency and the weak judicial capacity (see Table 4).

First, root causes for governance challenges include lack of transparency, public policy monitoring and evaluation, weak citizen oversight mechanisms and democratic culture, and a lack of institutional capacity to generate reliable data. Weaknesses have been identified at all stages of the planning, programming, budgeting, monitoring and evaluation cycle. Resources budgeted at the national level either arrive late or are insufficient, while resources at the provincial level are centralized and/or delivery capacity is low. The overall governance, business environment, and diversification indicators have remained unchanged and linear (Figure 1). Government policies and laws often do not establish clear rules of the game, and foreign firms can have difficulty navigating the bureaucracy. Despite reform efforts, hurdles and red tape remain, especially at the lower and mid-levels of the ministries. Lack of transparency in administrative procedures and lengthy bureaucratic delays occasionally raise questions for companies about fair treatment and the sanctity of contracts. The government does not publish proposed laws and regulations in draft form for public comment. There are no centralized online locations where key regulatory actions or their summaries are published. Therefore, citizens and the civil society have no means of control on the management of resources and this lower the trust of citizen and investors in the institutions. Many literatures have highlighted the benefit of transparency and agree that the openness associated with transparency serve as a 
Table 4. 2017 IIAG Gabon scores, ranks \& trends. (Score/100.0; 100.0 = best; Rank/54; *AAT: Annual Average Trend).

\begin{tabular}{ccccc}
\hline & Score & Rank & 10-year AAT & 5-year AAT \\
\hline Overall Governance & 52.2 & 23 & +0.37 & +0.03 \\
Safety \& Rule of Law & 53.1 & 25 & -0.03 & -0.30 \\
Participation \& Human Rights & 45.8 & 32 & +0.33 & +0.18 \\
Sustainable Economic Opportunity & 44.7 & 29 & +0.67 & +0.28 \\
Human Development & 60.7 & 17 & +0.49 & -0.03 \\
\hline
\end{tabular}

Source: 2017 Ibrahim Index of African Governance.

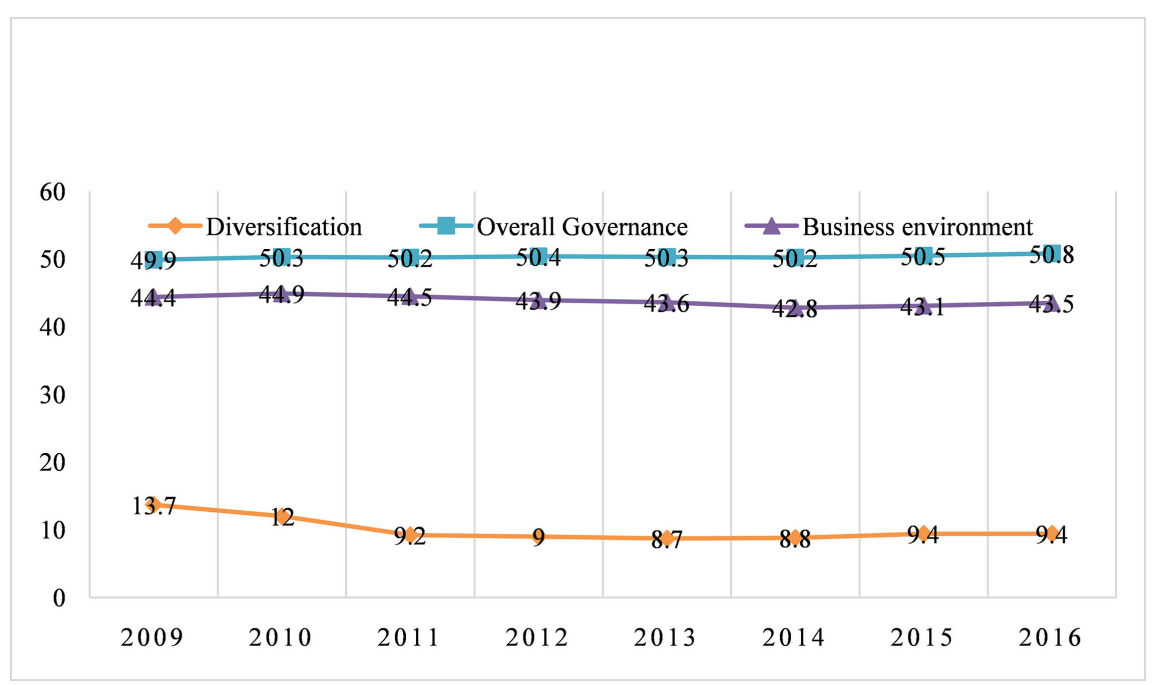

Figure 1. Governance, diversification, and business environment trend in Gabon (2009-2016). Source: Author's research based on Ibrahim Index of African Governance Data.

check on political actors as citizens are able to readily observe their actions accordingly (Coyne \& Leeson, 2009). It allows also the market participants to have the information they need to allocate resources efficiently (Ball, 2009). Other scholars have in contrary emphasize on some negative outcomes of transparency and argued that mere enforcement of rules and increased transparency could lead to criminal activity (Yang, 2008; Blinder, 2004) and could create in certain cases bureaucratic burden related to an obsession with public reporting and form will be an increase in transaction cost (Standing, 2010).

Second, bribery, gift practice, and corruption are widespread within the public administration. Despite the established legal framework to fight corruption, the enforcement remains moderate and official impunity is a problem. Corruption is rarely prosecuted despite the existing government established CNLCEI. Gabon ranks 117 out of 180 on the Corruption Perceptions Index 2017 of Transparency International with a score of 32 (100 is the highest). The above practices explain well the administrative burden, because efforts are made at the institutional level to tackle corruption; but not many efforts are done to fight bribery and gift prac- 
tices. Although the Penal Code criminalizes abuse of office, embezzlement, passive and active bribery, trading in influence, extortion, offering or accepting gifts, and other undue advantages in the public sector; these situations are rarely prosecuted. In addition, the CNLCEI regulations do not extend to family members of civil servants or to political parties. Measures adopted in 2010, among which: the civil service audit which highlighted the existence of ghost government employees; the effective application of the assets declaration principle by members of government and officials; and the announcement in April 2010 of the conduct of an oil sector audit to better determine financial flows from the industry did not result to any deep reform in the public administration. According to the Enterprise Surveys, companies contend with a high risk of corruption when dealing with the Gabonese extractive industries. As regards transparency in extractive industries, the Extractive Industries Transparency Initiative (EITI) Board decided in February 2013 to expel Gabon from the admission process for non-compliance with the reporting schedule. In November 2014, Gabon made new commitments for readmission to the EITI and in 2015 Gabon approved the plan and appointed a president of the group that will implement it, but as of now, there is not much information about the readmission stage.

In brief, in this section I identified three major constraints which affect the efficiency of the PSGE. First, the small market of Gabon has a negative impact on the investment especially foreign investments. Foreign investors are interested in sectors with high potentialities, but in the case of Gabon only natural resources have this potential because of the international demand of hydrocarbon and mineral resources; the size of Gabon's market may look insignificant for foreign investors to engage in activities oriented toward the domestic market. Second, many obstacles remain in the cycle of life of small and medium businesses. The reforms of the PSGE toward entrepreneurship remain concentrate in the business creation while improvements for the expansion of businesses are needed (e.g., ease the access to capital or loan, enhance the energy supply, improve the quality of transport infrastructures, etc.). Third, the institutional framework is weak; corruption, bribery, and bureaucracy have a negative impact on the business environment.

\section{Conclusion and Policy Implications}

This research argues that reforms from the PSGE did not bring considerable changes on the business environment in Gabon. The current macroeconomic situation of Gabon due to the barrel price has limited the capacity of the government to finance its major reforms. Furthermore, the small size of the market weakens the potential of the country to attract FDI in non-extractive sectors. Likewise, while reforms are made to ease the starting of business, access to capital and credit remain difficult especially for SMEs and it undermines their opportunity of growth and participation in sectors that create more wealth such as the extractive sector. In addition, the government regulation, poor infrastructure 
and corruption are quite damaging for established businesses and impact negatively the business environment upstream and downstream. The literature discussed, and findings of the current study provide three main policy implications. First, while some improvements of the business environment are costly and will take a long time to achieve, others can be achieved with few costs if there is strong political will. For example, the government can make major regulation with no cost such as making easier to pay taxes and improving the administration because the more bureaucracy, the more opportunities for bureaucrats to be involved in corruption. Moreover, the judicial system must be more efficient in punishing bribery, firms involved in corruption, and corrupt officials, hence extend the CNLCEI competencies and allow the civil society to play a role within the organization for more transparency. Second, the government has an important role to play in making the banking and financial regulations more efficient. For example, encourage the development of MFIs that will enhance SMEs access to credit and loans; and decrease substantially the cost and interest rates of financial institutions on the other hand. Third, in order to improve the quantity and quality of the infrastructures, the government needs to further the PPPs which is a financial alternative and less costly due to the level of indebtedness of the country. This improvement implies internal and external transportation networks to connect the production hubs with the markets and extend development opportunities to every region of the country. Likewise, transportation networks will contribute to connecting Gabon with other regional markets and hence enlarge its market size. Nevertheless, in order to achieve the latter, policymakers must advocate for regional integration through ECCAS countries. In addition, the country should also improve the energetic capacity in order to meet domestic and industrial consumption without disrupting economic activities; this would boost production. In summary, Gabon's diversification model features a resource-based diversification that succeeded in Nordic countries, but this model shows some weaknesses if the process is not followed by a coherent industrial policy. But in the meantime, alongside with reforms toward the business environment the immediate concern of policymakers should be the empowerment of SMEs through an effective financial framework favorable for entrepreneurship.

\section{Acknowledgements}

I am grateful to Professor Brice Obiang Obounou for his insightful and constructive suggestions. Incorporating these suggestions has improved this manuscript. I would like also to thank Abir Abdelli, Cristiano Gimmelli, Eze Ugochukwu, and anonymous reviewers for their constructive comments and suggestions on the early versions of this article.

\section{Conflicts of Interest}

The author declares no conflicts of interest regarding the publication of this paper. 


\section{References}

Acemoglu, D., Johnson, S., \& Robinson, J. A. (2001). The Colonial Origins of Comparative Development: An Empirical Investigation. American Economic Review, 91, 1369-1401. https://doi.org/10.1257/aer.91.5.1369

Acemoglu, D., Johnson, S., \& Robinson, J. A. (2002). Reversal of Fortune: Geography and Institutions in the Making of the Modern World Income Distribution. Quarterly Journal of Economics, 117, 1231-1294. https://doi.org/10.1162/003355302320935025

Acemoglu, D., Johnson, S., \& Robinson, J. A. (2003). An African Success Story: Botswana. In D. Rodrik (Ed.), Search of Prosperity: Analytic Narratives on Economic Growth (pp. 80-119). Princeton, NJ: Princeton University Press.

https://doi.org/10.1515/9781400845897-006

Acemoglu, D., Johnson, S., \& Robinson, J. A. (2005). Institutions as the Fundamental Cause of Long-Run Growth. In P. Aghion, \& S. Durlauf (Eds.), Handbook of Economic Growth (pp. 385-472). Amsterdam: North-Holland.

African Development Bank Group (2011). Republic of Gabon, Country Strategy Paper 2011-2015.

https://www.afdb.org/fileadmin/uploads/afdb/Documents/Project-and-Operations/Ga bon\%20-\%202011-2015\%20Country\%20Strategy\%20Paper.pdf

Arndt, C. (2008). The Politics of Governance Ratings. International Public Management Journal, 11, 275-297. https://doi.org/10.1080/10967490802301278

Ball, R. (2009). Market and Political/Regulatory Perspectives on the Recent Accounting Scandals. Journal of Accounting Research, 47, 277-323. https://doi.org/10.1111/j.1475-679X.2009.00325.x

Blinder, A. S. (2004). The Quiet Revolution: Central Banking Goes Modern. New Haven: Yale University Press. https://doi.org/10.12987/yale/9780300100877.001.0001

Bratton, M. (2013). Measuring Government Performance in Public Opinion Surveys in Africa: Towards Experiments?(WIDER Working Paper 2013/023). Helsinki: UNU-WIDER.

Brett, E. (2009). Reconstructing Development Theory. International Inequality, Institutional Reform and Social Emancipation. Basingstoke: Palgrave Macmillan. https://doi.org/10.1007/978-1-137-05768-6

Brixiova, Z., \& Ncube, M. (2013). Entrepreneurship and the Business Environment in Africa: An Application to Ethiopia (Discussion Paper No. 7553). Bonn: IZA.

Chang, H. (2011). Institutions and Economic Development: Theory, Policy and History. Journal of Institutional Economics, 7, 473-498. https://doi.org/10.1017/S1744137410000378

Chang, H. J. (2002). Kicking A way the Ladder. Development Strategy in Historical Perspective. London: Anthem.

Chang, H. J. (2010). Institutions and Economic Development: Theory, Policy and History. Journal of Institutional Economics, 7, 473-498. https://doi.org/10.1017/S1744137410000378

Coyne, C. J., \& Leeson, P. T. (2009). Media as a Mechanism of Institutional Change and Reinforcement. International Review of Social Sciences, 62, 1-14. https://doi.org/10.1111/j.1467-6435.2009.00421.x

Davis, K. E., Fisher, A., Kingsbury, B., \& Merry, S. E. (2012). Governance by Indicators: Global Power through Quantification and Rankings, Law and Global Governance. Oxford: Oxford University Press.

https://doi.org/10.1093/acprof:oso/9780199658244.001.0001 
Devarajan, S., \& Fengler, W. (2013). L'essor économique de l'Afrique: Motifs d'optimisme et de pessimisme. Revue d'Economie du Développement, 21, 97-113. https://doi.org/10.3917/edd.274.0097

Djankov, S., La Porta, R., Lopez-De Silanes, F., \& Shleifer, A. (2002). The Regulation of Entry. Quarterly Journal of Economics, 117, 1-37. https://doi.org/10.1162/003355302753399436

Drabek, Z., \& Payne, W. (2001). The Impact of Transparency on Foreign Direct Investment (Working Paper, Vol. 99/02). Geneva: World Trade Organization.

Durnev, A., Errunza, V., \& Molchanov, A. (2009). Property Rights Protection, Corporate Transparency, and Growth. Journal of International Business Studies, 40, 1533-1562. https://doi.org/10.1057/jibs.2009.58

Fofack, H. (2014). The Idea of Economic Development: Views from Africa (Working Paper No. 2014/093). Helsinki: UNU WIDER.

Gambotti, C. (2014). Gabon, pays émergent: Les ambitions du plan stratégique Gabon émergent 2025. Géoéconomie, 68, 159-170. https://doi.org/10.3917/geoec.068.0157

Gelb, A., \& Grasmann, S. (2010). How Should Oil Exporters Spend Their Rents? (Center for Global Development Working Paper 221). Washington DC: CGDEV.

Gisselquist, R. M., \& Niño-Zarazúa, M. (2015). What Can Experiments Tell Us about How to Improve Government Performance? Journal of Globalization and Development, 6, 1-45. https://doi.org/10.1515/jgd-2014-0011

Grindle, M. S. (2004). Good Enough Governance: Poverty Reduction and Reform in Developing Countries. Governance, 17, 525-548. https://doi.org/10.1111/j.0952-1895.2004.00256.x

Holmberg, S., \& Rothstein, B., Eds. (2012). Good Government: The Relevance of Political Science. Cheltenham and Northampton, MA: Edward Elgar.

https://doi.org/10.4337/9780857934932

Jones-Luong, P., \& Weinthal, E. (2010). Oil Is Not a Curse: Ownership Structure and Institutions in Soviet Successor States. New York: Cambridge University Press. https://doi.org/10.1017/CBO9780511779435

Kaufmann, D., \& Kraay, A. (2002). Governance without Growth. Economia, 3, 169-229.

Kaufmann, D., Kraay, A., \& Mastruzzi, M. (2003). Governance Matters III: Governance Indicators for 1996-2002 (World Bank Policy Research Working Paper No. 3106). Washington DC: World Bank.

Kaufmann, D., Kraay, A., \& Mastruzzi, M. (2005). Governance Matters IV: Governance Indicators for 1996-2004 (World Bank Policy Research Working Paper Series No. 3630). Washington DC: World Bank.

Kaufmann, D., Kraay, A., \& Mastruzzi, M. (2006). Governance Matters V: Aggregate and Individual Governance Indicators for 1996-2005 (World Bank Policy Research Working Paper No. 4012). Washington DC: World Bank.

Kaufmann, D., Kraay, A., \& Mastruzzi, M. (2007a). Governance Matters VI: Governance Indicators for 1996-2006 (World Bank Policy Research Working Paper No. 4280). Washington DC: World Bank.

Kaufmann, D., Kraay, A., \& Mastruzzi, M. (2007b). Growth and Governance: A Reply. Journal of Politics, 69, 555-562. https://doi.org/10.1111/j.1468-2508.2007.00550.x

Kaufmann, D., Kraay, A., \& Mastruzzi, M. (2008). Governance Matters VII: Aggregate and Individual Governance Indicators, 1996-2007 (World Bank Policy Research Working Paper No. 4654). Washington DC: World Bank.

Kaufmann, D., Kraay, A., \& Mastruzzi, M. (2009). Governance Matters VIII: Aggregate 
and Individual Governance Indicators, 1996-2008 (World Bank Policy Research Working Paper No. 4978). Washington DC: World Bank.

Kaufmann, D., Kraay, A., \& Zoido, P. (1999). Governance Matters (World Bank Policy Research Working Paper No. 2196). Washington DC: World Bank.

Kaufmann, D., Kraay, A., \& Zoido, P. (2002). Governance Matters II: Updated indicators for 2000-01 (World Bank Policy Research Working Paper No. 2772). Washington DC: World Bank.

Kirkpatrick, C. (2014). Assessing the Impact of Regulatory Reform in Developing Countries. Public Administration and Development, 34, 162-168.

https://doi.org/10.1002/pad.1693

Kirkpatrick, C., Parker, D., \& Zhang, Y. F. (2006). Foreign Direct Investment in Infrastructure in Developing Countries: Does Regulation Make a Difference? Transnational Corporations, 15, 143-171.

Klapper, L., Laeven, L., \& Rajan, R. (2006). Entry Regulation as a Barrier to Entrepreneurship. Journal of Financial Economics, 82, 591-629.

https://doi.org/10.1016/j.jfineco.2005.09.006

Knack, S., \& Keefer, P. (1995). Institutions and Economic Performance: Cross-Country Tests Using Alternative Institutional Measures. Economics \& Politics, 7, 207-227. https://doi.org/10.1111/j.1468-0343.1995.tb00111.x

Kurtz, M. J., \& Schrank, A. (2007). Growth and Governance: Models, Measures, and Mechanisms. Journal of Politics, 69, 538-554. https://doi.org/10.1111/j.1468-2508.2007.00549.x

La Porta, R., Lopez-de-Silanes, F., \& Shleifer, A. (2008). The Economic Consequence of Legal Origins. Journal of Economic Literature, 46, 285-332. https://doi.org/10.1257/jel.46.2.285

Lin, J., Monga, C., Willem te Velde, D., Tendulkar, S. D., Amsden, A., Amoako, K. Y., Pack, H., \& Lim, W. (2011). DPR Debate: Growth Identification and Facilitation: The Role of the State in the Dynamics of Structural Change. Development Policy Review, 29, 259-310. https://doi.org/10.1111/j.1467-7679.2011.00534.x

Lundvall, B., \& Lema, R. (2014). Growth and Structural Change in Africa: Development Strategies for the Learning Economy. African Journal of Science, Technology, Innovation and Development, 6, 455-466.

Mehlum, H., Moene, K., \& Torvik, R. (2006). Institutions and the Resource Curse. The Economic Journal, 91, 1-20. https://doi.org/10.1111/j.1468-0297.2006.01045.x

Ndzana Olomo, P. (2011). Réformes de l'environnement des affaires au Gabon. Marché et Organisations, 14, 97-128. https://doi.org/10.3917/maorg.014.0097

Ngangoue, F. (2016). Planifier et organiser la diversification économique en Afrique centrale. Revue Congolaise de Gestion, 21-22, 45-87.

https://doi.org/10.3917/rcg.021.0045

Nnadozie, E., Katjomuise, K., \& Krueger, R. (2008). NEPAD’s African Peer Review Mechanism and Investment Climate in Africa. In N. Grobbelar, \& H. Besada (Eds.), Un locking Africa's Potential: The Role of Corporate South Africa in Strengthening Africa's Private Sector (pp. 169-200). Johannesburg, Gauteng: University of Witwatersrand.

North, D. (1990). Institutions, Institutional Change and Economic Performance. Cambridge: Cambridge University Press. https://doi.org/10.1017/CBO9780511808678

North, D., \& Thomas, R. (1973). The Rise of the Western World: A New Economic History. New York: Cambridge University Press.

https://doi.org/10.1017/CBO9780511819438 
Oumba, P. (2015). Promouvoir une culture de la gouvernance en Afrique. In J. D. B. J. Didier, \& T. Laurent (Eds.), Gouvernance et lutte anticorruption en Afrique (pp. 106-117). Dakar: Presses de l'UCAC.

Parry, T. (2007). Transparency Aids Latin American Growth (IMF Working Paper 07/220). Washington DC: International Monetary Fund.

Robinson, J., Torvik, R., \& Verdier, T. (2006). Political Foundations of the Resource Curse. Journal of Development Economics, 79, 447-468. https://doi.org/10.1016/j.jdeveco.2006.01.008

Rodrik, D. (2008). One Economics, Many Recipes: Globalization, Institutions and Economic Growth. Princeton, NJ: Princeton University Press.

Sanders, A. R. D., \& Sandvik, P. T. (2015). Avoiding the Resource Curse? Democracy and Natural Resources in Norway Since 1900. In M. Badia-Miro, V. Pinilla, \& H. Willebald (Eds.), Natural Resources and Economic Growth: Learning from History. New York: Routledge.

Sokoloff, K. L., \& Engerman, S. L. (2000). Institutions, Factor Endowments, and Paths of Development in the New World. Journal of Economic Perspectives, 14, 217-232. https://doi.org/10.1257/jep.14.3.217

Standing, G. (2010). Work after Globalization, Building Occupational Citizenship. UK: Edward Elgard Publishing.

Stiglitz, J., \& Lin, J. (2013). The Industrial Policy Revolution I: The Role of Government beyond Ideology. New York: Palgrave Macmillan.

Teksoz, U., \& Kalcheva, K. (2016). Institutional Differences across Resource-Based Economies (WIDER Working Paper 2016/63). Helsinki: UNU WIDER.

Thomas, M. A. (2007). The Governance Bank. International Affairs, 83, 729-745. https://doi.org/10.1111/j.1468-2346.2007.00649.x

United Nations Conference on Trade and Development (UNCTAD) (2018). Investment and New Industrial Policies (World Investment Report 2018). Geneva: UNCTAD.

Venables, A. (2016). Using Natural Resources for Development: Why Has It Proven So Difficult? The Journal of Economic Perspectives, 30, 161-183. https://doi.org/10.1257/jep.30.1.161

Yang, D. (2008). Integrity for Hire: An Analysis of a Widespread Customs Reform. The Journal of Law and Economics, 51, 25-57. https://doi.org/10.1086/520007 


\section{Appendix. Business Reforms in Gabon}

\begin{tabular}{|c|c|}
\hline Year & Doing Business reform making it easier to do business \\
\hline 2018 & $\begin{array}{l}\text { Starting a Business: Gabon made starting a business easier by } \\
\text { reducing the paid-in minimum capital requirement and by } \\
\text { making the notarization of incorporation documents optional. } \\
\text { Dealing with Construction Permits. Gabon made dealing with } \\
\text { construction permits faster by streamlining the process and increased } \\
\text { transparency by publishing regulations related to construction online } \\
\text { free of charge. }\end{array}$ \\
\hline 2017 & $\begin{array}{l}\text { Resolving Insolvency: Gabon made resolving insolvency easier by } \\
\text { introducing a new conciliation procedure for companies in financial } \\
\text { difficulties and a simplified preventive settlement procedure for small } \\
\text { companies. }\end{array}$ \\
\hline
\end{tabular}

Starting a Business: Gabon made starting a business easier by reducing the paid-in minimum capital requirement.

Registering Property: Gabon made transferring property less costly by lowering the property registration tax.

Protecting Minority Investors: Gabon strengthened minority investor protections by introducing greater requirements for disclosure of related-party transactions to the board of directors and by making it possible for shareholders to inspect the documents pertaining to related-party transactions and to appoint auditors to conduct an inspection of such transactions.

Paying Taxes: Gabon made paying taxes easier for companies by introducing an electronic system for filing and paying VAT.

Starting a Business: Gabon made starting a business easier by replacing the requirement for a copy of the founders' criminal records with one for a sworn declaration.

Dealing with Construction Permits. Gabon made dealing with construction permits easier by reducing the time required to obtain a building permit and by eliminating the requirement for an on-site inspection before construction starts.

Paying Taxes: Gabon made paying taxes less costly for companies by reducing the corporate income tax rate.

Getting Credit. Access to credit in Gabon was improved through amendments to the OHADA Uniform Act on Secured Transactions that broaden the range of assets that can be used as collateral (including future assets), extend the security interest to the proceeds of the original asset and introduce the possibility of out-of-court enforcement.

Getting Credit. In Gabon and other members of the Central African Monetary Union, the regional public credit registry provided online access to information for banks, simplifying the task of filing and retrieving information in the public registry and allowing expanded coverage of borrowers.
Change making it more difficult to do business

Dealing with Construction Permits. Gabon made dealing with construction permits more complicated by increasing the time required for obtaining a building permit.

Paying Taxes: Gabon made paying taxes more costly for companies by reducing the depreciation rates for some types of fixed assets.

Registering Property: Gabon made transferring property more costly by increasing the property registration tax rate.

Registering Property: In Gabon registering property became more difficult because of longer administrative delays at the land registry.

Trading across Borders: Gabon made trading across borders more difficult by introducing an additional document for importing or exporting. 